\title{
EDUCATIONAL ETHOS, CHANNEL OF INNOVATION IN THE EDUCATIONAL INSTITUTION
}

\author{
Alfredo Rodríguez-Sedano ${ }^{1}$, Luz Yolanda Sandoval ${ }^{2}$ and Ana Costa-Paris ${ }^{3}$
}

\begin{abstract}
The goal we propose in this paper is to see how the development of the teaching ethos is a channel of innovation in the educational institution. Yet at the same time it could be argued that the ethos is the channel of innovation in any social environment in which it manifested. We begin by focusing on innovation and seeing its manifestation is extensive within the social framework. Next we outline one of the difficulties innovation faces: the stupor. This allows us to highlight that innovation is essential in the novelty of the innovative action in accordance with the attitudes of those who carry out this action. The novel character puts more emphasis on individuals than on the processes that all innovation involves. The notion of field emphasizes that virtue is key to better understand innovation. The virtues and the conditions that are key to who innovates will be addressed. At this point, if the ethos or character is the mode of personal being self-acquired in the daily exercise of freedom itself, it will be the natural channel through which innovation must be carried out. We will examine the ethical virtues that make up the teaching ethos, finding there the nexus between ethos and innovation. Finally we point out that the proposal about the virtues that accompany the teaching ethos can be extended, basically because in practice the teaching ethos is indiscernible from the human ethos, and because the personal imprint made on what has been done basically depends on the human ethos.
\end{abstract}

Keywords - educational Ethos, innovation, virtue, field, ethics

\section{INNOVATION AND SOCIAL FRAMEWORK}

It is somewhat striking the abundant literature that can be found on this subject either specialized or not [1]. Perhaps such a proliferation on one hand, can lead to some confusion on what is meant by innovation and decision-making, on the other hand, to the expressed desire to clarify what is meant by innovative [2]. As Nueno says, "everyone would like that there were more entrepreneurs, but it is not clear what it is or how the entrepreneurial spirit is stimulated" [3]. Nowadays innovators are everywhere and in decision-making a series of techniques that predict the success of the decision taken is established, for the sake of profitability it can produce. Moreover, in the last years the knowledge society has emphasized the need for innovation in organizations. It is no longer enough to have one or two managers with ideas. The ability to innovate has become a competitive advantage to be developed in all members of an organization at the level everyone is. This way, Drucker is among those who believe that innovation is not restricted to a group of individuals with special qualities; instead the innovative character can be developed in the company among those who belong to the organization to provide a competitive advantage [4].

${ }^{1}$ School of Education and Psychology University of Navarra (Spain)

${ }^{2}$ Faculty of Education University of La Sabana (Colombia)

${ }^{3}$ School of Education and Psychology University of Navarra (Spain) 
As background, the reflections to be presented here are chaired by a clear consideration: it is the person who innovates and makes decisions. As rightly pointed out by Melee, "the objection about what the entrepreneur is refers not only to descriptive aspects, but to something deeper, what is the philosophical anthropology of entrepreneurial initiative. However, until now, it has been given little attention. And it is striking, because entrepreneurial initiative is, above all, human action, related to various human abilities such as creativity, knowledge and forecasting purposes, the permanent dispositions of character (virtues) and especially, the human capacity to act freely" [5]. A review of the literature between the entrepreneur and ethics can be seen in Hannafey [6].

Innovation in its infancy is linked to the approach that economists give it. Initially [7] innovation tends to be polarized in the process and outcomes of entrepreneurial initiative, but it is nonetheless true that the reference to the entrepreneur's human condition through a set of personal qualities that are required for the process is key to greater and better understanding of what innovation is, so that if initially it was typical of a field, the entrepreneurial, today we talk about innovation in all areas that are unique to the human condition. Innovation is not confined to a field but all of those in which human interactions take place. Basically what we want to point out is that innovation is not understood in its origin as a process, although it is in its manifestation and therefore we speak of innovation, but it is based on the agent that carries out this innovation.

\section{THE DIFFICULTY OF INNOVATION: THE STUPOR}

According to the social framework in which innovation is inscribed, if something globalization shows is that the in world we live in individualism is not the best recipe for solving the new problems that we are to face. But neither are the ideologies. The opening to the world we live in, giving human action the purpose of sense that is its own, constitutes the best way to meet new challenges and new opportunities. In other words, a take on reality, a knowing how to materialize ideas, and making projects operative "And this is achieved by a kind of connatural knowledge, because knowledge beat vibrates with the same rhythm as the beat of reality"[8].

The truth requires the ability to admire one self, to see reality innovatively, because what admiration involves is the sustained attention to reality. The paradigm of truth enhances the preeminence of reality and excludes the causal nature of knowledge, while the paradigm of certainty means that the cognitive activity of man is constitutive, assuring the causal nature of knowledge, that is, by reducing knowledge into intellectual construction of an ideal system.

A clear difficulty with which innovation collides is certainly the attitude of stupor at the complexity that, in the best case scenario, makes us silent witnesses of reality. Indeed, as noted by Polo [9], "admiration can derive, not anymore to the suspicion that one is little capable, but to the idea that truth is unattainable. What is admirable would then be admirable, but would be outside the scope itself. This is traditionally called stupor, and differs sharply from admiration. Admiring is not being astonished; stupor is a waiver. Admiration turns into its opposite, that is, pessimism. It is as if it were compulsory to stop looking because it it is not worth insisting. While admiration connects to hope, astonishment is a vice, an unjustified waiver. The astonished desists for convenience: finding out about the truth is very difficult, or impossible. The astonished is devoted to something easier, something already known, to what is familiar: there are sure things, ascertained, for instance, how to make a bridge or a house. "Stupor helps to realize that nowadays we see in people an inability to know what is real. In other words what constitutes a real basic need that is to be satisfied? The proliferation of phenomena we call 
innovation disconnected from the common good, constitutes a real difficulty understanding what innovation clear is.

\section{III.THE NOVELTY NATURE OF INNOVATION}

From the discussion so far we could indicate that

- Anyone in the organization can be innovative.

- The innovative task entails an active posture by the person who innovates.

- Implies a certain ability to perceive reality differently.

- When carried out in an uncertain environment, it involves an element of risk.

- Requires an organizational structure as field in which innovation can manifest.

However, the essential thing is the novelty that the innovative action provides in accordance with the attitudes of those who carry out such action. The nature of new innovation allows to root innovation into who innovates and to place more emphasis on those processes that lead to all innovation.

If the focus is placed not on the innovator but not on the person acting as an innovator, we will be most likely to observe that this function that accompanies innovation, has its origin in the donative nature of the person, as it is proper to the person to donate or offer. The person inasmuch as he/she is donative, he/she opens, and within such opening, he/she is able to meet the needs that must be satisfied, in a way that his/her offering becomes a novelty -creativity- for those who require the satisfaction of a need. The enrichment of the manifestation- that is innovation- lies in that "the manifestative being -the person- is the one who when performing, puts something exclusively own and gives it to others: an intimacy that opens" [10].

Any offer leads to a novelty that makes the offering - innovated- have that added value and make it valuable for those in need. The person is the only being able to offer something new, that no one else can give more than him or herself. It gets even more evident in the knowledge society how the valuable is perceived through the innovative product, in whom is able to notice, more than any other, the needs and ways of meeting them. It is through knowledge, according to the above, how one can impact the processes already in place and reconduct them -granting them the innovative nature-, producing such imbalance that leads to profits for those who have been able to innovate.

Interestingly and so very different than it is perceived today, innovation viewed from the person who innovates is quite contrary to individualism. Hardly is one able to innovate unless we take into account each other's needs as well as the best way to meet them. Hence, innovation refers directly to social action, interaction of various actors where such a relationship is established for the exchange that takes place in accordance with what has been innovated and required by the one or those whom innovation is addressed to. And thus, by the process and status featuring innovation, knowledge should be emphasized as a third feature that makes it more understandable.

\section{IV.THE VIRTUE TU UNDERSTAND INNOVATION}

Innovation as a manifestation requires a field where it can be recognized. It is appropriate to briefly dwell on the notion of field to see how virtue is required to fully understand innovation [11].

A proper interpretation of field is carried out by Martin Lopez [12] when he notes that "it consists of relationships among individuals, which are cognitively based on representations and which have the coherence provided by attitudes maintained among individuals, institutionalized patterns and goals pursued in a more or less permanent way. " 
From this definition we can highlight three characteristics of the field:

1. It is relational;

2. It has a cognitive basis;

3. It holds coherence in attitudes.

The first thing warned in the interaction, and therefore in the plexus of interactions, is that it is relational. In such relationship something is looked for because otherwise the sense of relationship would be meaningless. That which is sought is common good which makes up and features the relationship and this is what attracts and makes it effective At the same time this is what allows to differentiate a relational field from one another.

However, the existence of such common good requires knowing it as such, since only the warning of something, -the knowledge of truth that accompanies it-, makes it possible to want it and move to its achievement.

At the same time, this knowledge of the common good pursued in the relationship calls for coherence in attitudes. Coherence, which requires from those who act, the effort in achieving such common good. Put differently, exercise and implementation of virtues that ensure the achievement of the known. By doing so, the relationship facilitates and ensures personal growth to the extent that the acquisition of new moral habits opens the doors to achieve higher purposes, which are likely to be known.

According to this characterization, "the field is a personal dimension of all social phenomena, whether it has to do with global society (macrosociological level) or as a simple social relationship (microsociological level)" [13].

Why virtue is emphasized as essential to understand innovation? Simply because it is only possible to open to higher purposes through virtues to the extent the virtue enables subsequent actions. Unless virtues are present, our knowledge will be limited to the purposes one opens to, thus reducing the framework of reality to which one opens. In daily experience we see how the different ways of approaching reality involve the personal mark of those who know them and their greatness of mind.

The educator who wants to innovate not only requires knowledge but virtue, which will makes it easier to him/her when taking over the reality that surrounds him/her. The ethical dimension is inseparable from the innovative nature [14] and is an excellent way to ensure the effectiveness of what is intended, as "technology and ethics are presented as two realities-more precisely, as two dimensions of the same reality, different from one another, but not opposite or heterogeneous, on the contrary called to a close rapport " [15].

In the relationship, the exercise of moral habits--third dimension of the field as suggested by Martin Lopez- assures us growth and the development of intellectual habits to the extent that moral habits allow us to open to higher purposes, as noted before. We could say that the intellectual torpor -difficulty, in this case to appreciate the need for the other or others- is cause of the moral torpor- the genuine of individualism- when ignoring that what is being on spot in the relationship is my being a person with all that dimension entails in its manifesting field. And, therefore, when the intellectual torpor tries to satisfy needs, it impacts more in the creation, understood as a process and situation -which in assessment-understood as an opening that includes the process and status- of the need, prioritizes and stars the instrumental rationality. Creativity, proper of innovation as it is being considered, should be moved more to the order of the means than of the purposes.

The innovative nature is attached to the common good that is pursued in the relationship. This aspect is also evident in the relationship between learner and educator, when education is seen as 
helping to grow. If the good being innovated has little or nothing to do with the needs of others, it is simply not accepted. That is, what aims to be an innovation is not an innovator itself, not because the subject does not appreciate it as such, but because this lack of appreciation is given by the existing disconnection between what is offered and the need required to the extent that one has not taken over the situation. What has actually happened? A plausible answer can be offered by saying that there is no offer. Any offer requires the search for the good of the other so it can really be offered and accepted. In the acceptance, it is clearly seen that what has been donated - the innovation- acquires the true sense and both grow out of that relationship.

The notion of field shows us that innovation requires a space -the educational institution as a community of persons in the service of society [16] - so it can actually take place. But the very notion of field marks the guidelines of how such relationship is to be carried out.

\section{V.WHAT CONDITIONS AND VIRTUES DOES THE INNOVATOR REQUIRE?}

According to what has been said about innovation, it is time to address, in a practical way, the conditions required by innovation from the personal nature and which are the virtues that claim those conditions for the proper exercise of innovation. These conditions we are going to approach are a first approximation to the issue noted in the introduction when Nueno stated, "it is not clear how to stimulate the entrepreneurial spirit." We will try to address this issue in this section which will let us link to the educational ethos, as the virtue is the common element between the educational ethos and innovation.

The first condition required is a permanent attitude of openness to the real. The innovative action comes initially marked by a need to satisfy needs (own and others), releasing the innovator from its own confinement to direct his/her own intelligence, will and senses -in the form of personal openness- to the other or others where a need is observed as a main aim. One can speak of a service component in such opening, which is related to the virtue of wisdom, "habit whereby suddenly one knows to find what is better " (S. Th II-II, q. 49, a. 4) but with temperance (S. Th IIII q.141 a.1) and hope as well (S. Th II-II, q. 128, a.1, ad.2) to the extend that the first lies in the meaning of moderation while the second is willingness and confidence. Along with these virtues, the attitude of openness also keeps a special relationship with the virtue of humility, which is coherent, initially, to leave one's own confinement and thereby, openness to the actual need can respond to the needs of others. "Humility is some disposition for individuals to have free access to the spiritual and divine goods" (S. Th II-II, q. 161, a. 5, ad. 4). That is, an open path to that, which is beyond ourselves. The virtue of humility is so important that its existence "involves the conservation and foundation of other virtues in its being" (In III Sent., D. 33, q. 2, a. 1, q. 4, ad 3) . In other words, the importance of this virtue should not only be taken as it is considered in itself, but also in relation to the other virtues for it reinforces and fosters them, so humility assumes the existence of the other virtues in humans, virtues that are reflected in their way of being and acting. This first condition helps to bridge the gap in the relationship as the innovator is called, for the needs of others, to seek new opportunities and alternatives that make these opportunities feasible. Openness manifests the offering that giving involves.

The second condition required is precisely the relationship. Altarejos and Naval claim that "relationability, communicability or transcendence of the person are merely different names of its constitutive opening, which can also be referred to as coexistence." As we open ourselves, closeness and intimacy grow too, understanding that "intimacy is not the closure of subjectivity itself, but on the contrary, it is the core of the radical openness of the personal being to others" [17], thus, enhancing this way the initial arrangements observed in the first condition. Starts a genuine process of personal attention and knowledge which should lead to meeting needs and the 
improvement of the one who innovates. Coexistence, as openness, is taking form of relationship. In this way, a strong element of personal struggle is given by the one who innovates,- asceticismexercise of the virtues, especially of the fortress (S. Th II-II, q. 123, . 1), friendship (S. Th II-II, q. 23, a. 2) and constancy (S. Th II-II, q. 137, a. 3, ad.3) - in the consolidation of the inner disposition to carry out innovation. But the most valuable of the relationship gives us coexistence that allows us to grasp the need and satisfy it as it really requires to be. Coexistence grants relationship all its meaning, its full value, overcoming proceeding, or rather, understanding the procedure in the correct interpretation means-purposes. Coexistence, this being-with-other, calls the innovator to participate in the needs of others.

The third condition would be the science the innovator counts on. Openness and relationship lead the innovator to paths of intimacy, personal effort and the exercise of virtues. But the one who innovates performs in a concrete personal, educational, family, social and cultural context. That personal condition and context is reflected in the innovation and assumed by those who accept such innovation. To help us get around in that environment there is this condition. Its theoretical goal is to enlighten about the truth of man -as a being that experiences needs and the world he inhabits, then what has been innovated affects him by humanizing him. For this purpose, understanding penetrates and captures the truth. The virtue required is veracity, virtue that "means the truth in words and gestures, that is, the conformity of what is believed or thought with the external behavior" (S. Th II-II, q. 109, 1). And next to veracity comes justice, "organize the individual with the things that are related to the other" (S. Th II-II, q. 57. a. 1). Between these two virtues is a mutual relationship. Indeed, "the virtue of truth coincides with justice in two notes: one, in referring to the other. And in fact, manifestation is an act of truth aiming at someone else, as a man is to another to whom he exposes what he carries within himself. The second, in that justice establishes certain equality among things, which is the same that makes the truth establish an equation between the signs and the reality of what is inside (...) the truth is part of justice, as a secondary virtue, it is attached to it as a primary virtue "(S. Th II-II, q. 109, 4). The practical aim of science is indeed to educate about the truth in a right judgment that organizes adhesion of the truth and the rejection of opposite errors. But the practical dimension would be mistaken without the advice of Science, as the counseling's own mission is precisely to consider the practical application of correct judgments formed on the truth to individual actions. This third condition is key to practical and theoretical solution so that the innovated product acquires the innovative nature. Science has started to bear its best results when openness and the relationship make it easier for the innovator to get in tune with the real needs that must be met.

The fourth condition is the fortress required. With opening, relationship and Science the innovator is embarked on an effort to achieve the intended purpose. St. Thomas (S. Th. II-II, q. 123, a.6) teaches that the fortress is present in two fundamental actions: aggredi y sustinere, facing the dangers that may involve the realization of good, and bearing adversities that come upon for a fair cause. In the first case courage and audacity are found; in the second, patience and perseverance. Now, the one who faces this path with strength is able to overcome assuring success in the task started. The creativity that the job demands is a common task to which everyone is called upon due to the coexistence in which the work unfolds. In fortress the innovator finds the necessary means to carry out that action that he is unable to perform by himself. Pointing out this condition in fourth place has a sense to be clarified. From the gradual perspective of life, it is the middle years which more needed of this condition are. The experience, a good counselor, may play against. The uncertainty in which innovation performs requires overcoming the obstacles presented at that stage of life, addressing more ambitious goals. In those years, the perseverance, 
patience [18], constancy in the fight against own acquired defects, to help more effectively with meeting needs, require a special exercise of the fortress which is not present at the at the beginning of the innovative activity. They are moments in lives of people where there may be more conformism if the first condition is forgotten. Perhaps this is why this condition is what ensures and encourages, at all times, the innovative action.

The fifth condition needed is the one to ask for advice. We must go to others because in spite of the amount of Science we have, the complexity of many events "requires consideration of many factors, barely observable by just one, which may instead be more likely perceived by many, because what does not come to one's mind; may come to others' (S. Th. I-II, q. 14, a.3c). And at another time points Aquinate (S. Th. I-II, q. 49, a.3c) that "in regards to prudence the individual needs to learn from others", because he is not enough for himself; that's why, "the first act of prudence should be asking for advice" (S. Th. I-II, q. 47, a.8), count on others' experience, and seek their advice. Involving others, those around you, in such innovative action means reading in one's interiority and enriching one's own intimacy.

This virtue requires two essential virtues: humility - not to trust self-judgment- and docility knowing how to share various performance criteria. Through counseling the innovator is able to make the right decisions by the means of events which apparently seem trivial. In such condition, emerges the uncertainty associated with innovation. Taking or not taking advice is to assume the risk associated with uncertainty. However, the conditions pointed before, somehow soften such uncertainty and especially prudence as "perfective faculty of every moral virtue" (S. Th. II-II, q. 166, a.2, ad 1). If the first condition highlights the nature of service as a precondition for the innovative action to take place, seeking for advice turns to be essential for the successful completion of that action. Nevertheless, this condition does not elude the freedom in following the advice or not, and the responsibility assumed in the decision taken.

From opening to counseling a number of conditions have been stated, from which arise the virtues an innovator must live. In a schematic way, the conditions and virtues are reflected in the chart below (Table I).

\begin{tabular}{|l|l|}
\hline Table I. Conditions and virtues required for innovation \\
\hline Conditions & Virtues \\
\hline A permanent attitude of openness to the real & Sagacity, Temperance, Hope and Humility \\
\hline The relationship & Fortress, Friendship and Constancy \\
\hline Science & Veracity, Justice \\
\hline Fortress & Courage, Audacity, Patience y Perseverance \\
\hline Asking for counseling & Prudence, Humility and Docility \\
\hline
\end{tabular}

Source: Rodriguez 2012, pro manuscrito

It is not a matter of perceiving these conditions as a closed model. That view is quite the opposite of what it represents and it is the human being who carries out a job from which he/she seeks to improve through the exercise of virtues. Precisely, when highlighting virtues, and as they are specifically human, innovation can and must be required from anyone who works or does other activities that contribute to social improvement. In other words, innovation is not a condition of work, but of those who work. Innovation covers all areas of the social sphere. That is why the conditions listed are valid for any of the fields where such kind of action is carried out. 


\section{VI.WHAT CONDITIONS AND VIRTUES DOES THE INNOVATOR REQUIRE?}

So far we have focused on innovation, its meaning, what innovating means, and what features the one carrying out innovation requires. Now, it is time to ask for the channel through which innovation takes place in a natural way within the educational institution. The answer to this question comes from what has been said. If virtue is the key to innovation, the educational ethos will be the natural channel through which innovation must be carried out. Let us briefly focus on this issue to discern why we have noted that the ethos is the proper channel for innovation.

The ethos is, above all, the way to be one's own free agent, from which one is possessed in and through the deliberated action. The ethos or character is the way to be personal and self-acquired in the daily exercise of personal freedom. "For Aristotle, human development requires an initiation into a culture in which the qualities and the character of the person are recognized and implemented. This is important, to note that not all processes can be reduced to mere socialization" [19].

Anthropological and psychological complexity of the human being prevents from understanding him in direct and immediate consideration, and even less in simple suggested propositions. "The concept of ethos is notoriously difficult to analyze, at least for two reasons. In first place, the concept of ethos is very similar to, and often described in terms of concepts related to 'environment', 'atmosphere', 'weather', 'culture', 'ethical development' and others of the same kind. Therefore, it is difficult to meet the specific meaning of ethos for the purpose of analysis and discussion. Second, the intangibility and the elusiveness of the notion of ethos can be seen in broad aspects of life and classroom and school work through its manifestations and in a broader sense, through ways to influence on what has been expressed above. This broad sense of aspects and modes can be illustrated by reference to the recent Scottish and Irish initiatives in relation to the ethos of the school" [20].

Knowledge of the ethos can only be done by analytical ways, that is, through the study of its constitutive elements habits. As Goethe states, (Adagios en Prosa, $\mathrm{n}^{\mathrm{o}} 36$ ) "If we intended know everything accurately, we may know things better". Professional habits can be studied taking into account certain preliminary and basic conditions [21]:

- $\quad$ must be taken together,

- $\quad$ are not exclusive to a profession,

- $\quad$ professional habits are not the only habits in each professional,

- $\quad$ are specifications of common human habits.

Habits are the various qualities that show the subject, as a result of development of different human operational capabilities, congenital and acquired. Although, a habit is also a custom, it is not mainly it, and this has a routine dimension, of continuous repetition of acts. However, a habit is the specification of a person's way of being. Professional habits are characterized by:

- be unavoidable in their formation,

- be operatively defining of the nature of the profession,

- be configurative elements of personal professional character,

- be the central notions of deontology.

Virtue is the potential that contributes to the action for the future; it is the consideration of the habit as it implies an operative energy in the agent. As pointed by Aristotle in the Nicomachean Ethics $(1107$, a. 1), "virtue is a state of character referred to choice, linked in a relative sense to us, being determined by the rational of practical wisdom and the path the person determines".

The educational ethos is the way of being that takes shape in the educator by teaching practice and is manifested in its consistency of life, realizing that his work is of great use to advance in his own 
humanization or personal growth. Education will be highly qualified if educators in educational institutions manage to make of their own work an ethical act; "as a professional, the educator must act ethically and professionally as a person that manages people, and give that reciprocal relationship established a good moral sense: it must be a good personal act, in itself and its consequences. It must be a good educator, being a good educator", [22]. Building his educational character and making a commitment in the task performed, he will be an effective and ethical professional.

The educational activity of a good educator and good teaching is framed within the task of managing the student to acquire the capacity to govern himself and his own life, which implies a constant and ongoing commitment so that he himself, reinforced in his action, achieves personal improvement. And this is possible because as he is a teacher, the educator becomes an authority and a responsibility for the student. Authority that is reflected in the learning process of the student; who makes every effort to follow the teachings of the educator and tries to know what the educator teaches him from a concrete context.

The educator that has the authority is the one who cultivates the educational ethos. That is, those who cultivate the virtues which make up the professional ethos and give it the recognized authority for his knowledge and for his knowing how to seek for good. Once authority is understood, one can actually say that is enough as long as the educator is conscious that growing such virtues is essential to the development of his work, and keeps him companied throughout his lifetime. We coincide in that besides the development of the professional ethos, there is the human ethos, which is closely linked to the professional ethos.

From a synthetic point, we could point out a proposal that configures the fundamental virtues of the educational ethos. They are (Table II):

\begin{tabular}{|l|l|l|l|}
\hline \multicolumn{3}{|l|}{ Table II. Fundamental Virtues } & Higher Virtues \\
\hline Basic Virtues & Fortaleza & Justice & Prudence \\
\hline Temperance & Courage & Equity & Sagacity \\
Humility & Audacity & Veracity & Circumspection \\
Meekness & Rerseverance & Righteousness & Docility \\
studiousness & Patience & & \\
& &
\end{tabular}

Source: Altarejos [23]

\section{VII.DISCUSSION}

The proposal noted does not forget that virtues shape the fabric of the educational ethos, they can be theoretically discernible but inseparable in practice [24]. However, it is advisable to make some qualifications that must be present for a better understanding of the virtues as shapers of the educational ethos [25]:

They are not as exclusive to the educational ethos. Indeed, some, many can even shape the ethos of other professions, but they will not have the same level of priority or precedence.

These virtues must be considered together. When dealing with the educator's virtues, none of them can be considered separately, neither a selection of which can be considered more valuable or estimable. They themselves cannot define the educational ethos otherwise you give up the unity of the ethical life, which all professional fields claim for in order to effectively promote personal integration, which is, the humanization of working life. 
They are not unique in each professional. In addition to the virtues that make up the educational ethos, it is possible that other virtues are developed meanwhile, and it even seems to be meant this way. The human being is a person, and as such he/she essentially exceeds the material and formal conditions of an activity, no matter how embracing and extensive it is. There is a professional ethos, but it must take place within a personal ethos. Not only does this involve the modulation of the professional habits, but also the development of some others as subjective contribution to the professional practice: these define the personal style within the professional ethos.

The virtues that make up the educational ethos are specifications of human virtues. It should be noted that the profession does not cover all dimensions of existence; a professional performs well in other fields which involve other common possibilities of development. Moreover, a profession somehow emplaces other proper human faculties, otherwise, work will be dehumanizing as it will threaten the integrity and unity of the person [26]. Thus, professional habits can be seen as concretions, and as specifications for the ordinary human ethos.

According to these specifications, it is clear that the proposal indicated on the virtues that accompany the educational ethos can be extended, basically because in practice the educational ethos is indiscernible from the human ethos, and because the personal mark on what has been done, primarily depends on the human ethos. Here lies the relevance of highlighting the idea of the educator. An educator that professes knowledge and transmits it by takes care of the situation of every one, and pays attention to the diversity of individuality of the personal uniqueness, which is the student. Hence the educational ethos is the most proper and natural channel of innovation in an educational institution.

\section{CONCLUSION AND IMPLICATIONS FOR FURTHER RESEARCH}

According to what has been said, innovation must be understood in a broader framework than the one it is being considered. The market as a manifesting field for the innovator, through which economic exchanges take place, must look at these other fields in which the human being is reflected. The plexus of relationships helps establish a more realistic situational logic than the one it designs by itself and which is apart from other fields, the market reality.

Moreover, the innovative nature, as it refers to the person that innovates, considers how one should carry out the decision which certainly belongs to the entrepreneur, but without leaving the plexus of relationships. Stated this way, the innovative nature does not depend on subjectivity from the one who requires meeting a need, but rather looks at the personal improvement -in all its dimensions: personal, educational, social, economic, etc. - of the one innovating and who benefits from such innovation -as both interact-.

The conditions outlined attempt to provide the innovator with the stimulus he needs in such actions. In this framework, the exercise of certain virtues assures the effectiveness expected and the improvement of the performer. From this view, innovation must be understood for its calling nature, the strong social character it promotes, and the social participation it enhances. Besides, the educational ethos, natural channel on which the educational institution should rely, intends to be innovative as through this ethos the educator leaves a mark of the novelty of its offering. How to materialize such channel opens the door to future research. From the perspective of the educational ethos, innovation is not a condition of work but of the one who works. how to articulate it would require further study. 


\section{REFERENCES}

[1] A. Heertje, "Schumpeter on the Economics of Innovation and the Development of Capitalism", Elgar, Cheltenham, 2006.

[2] R.A. Buchholz, and S.A. Rosenthal, 'The spirit of entrepreneurship and the qualities of moral decision making: toward a unifying framework', Journal of Business Ethics, Vol. 60, pp. 307-315, 2005.

[3] P. Nueno, 'El emprendedor: deficiniciones y mitos', Inicitaiva emprendedora, vol. 2, pp. 21-24, enero-febrero, 1997.

[4] P. Drucker, P, 'Innovation and Entrepreneurship' Harper \& Row, Nueva York, 1985

[5] D. Melé, 'Dimensión ética de la iniciativa emprendedora', Consideraciones éticas sobre la iniciativa emprendedora y la empresa familiar, p. 24. Eunsa, Pamplona, 1999.

[6] F.T. Hannafey, 'Entrepreneurship and ethics: a literature review', Journal of Business Ethics, Vol. 46, No. 2, pp. 99-110, 2003.

[7] T.K. McCraw, 'Prophet of Innovation: Joseph Schumpeter and Creative Destruction', Harvard University Press, Cambridge, MA and London, 2007.

[8] F. Altarejos, A. Rodríguez, J. Fontrodona, 'Retos educativos de la globalización. Hacia una sociedad solidaria', p. 10, Eunsa, Pamplona, 2007.

[9] L. Polo, 'Introducción a la Filosofía', pp. 36-37, Eunsa, Pamplona, 2002.

[10] L. Polo, 'Ética. Hacia una versión moderna de los autores clásicos’, p. 75, Unión Editorial, Madrid, 1997

[11] B. Dyck, and R. Kleysen, 'Aristotle's virtues and management thought: An empirical exploration of an integrative pedagogy', Business Ethics Quaterly, Vol. 11, No. 4, pp. 561-574, 2001.

[12] E. Martin, Familia y Sociedad. Una introducción a la sociología de la familia', p. 46, Rialp, Madrid, 2000.

[13] E. Martin, Familia y Sociedad. Una introducción a la sociología de la familia', p. 47, Rialp, Madrid, 2000.

[14] O. Fisscher, et al, 'Stretching the frontiers: exploring the relationships between entrepreneurship and ethics', Journal of Business Ethics, Vol. 60, pp. 207-209, 2005.

[15] J.L. Illanes, Illanes, J. L, 'El mercado: ética y eficiencia', in Ética, mercado y negocios', p. 597, Eunsa, Pamplona, 1994.

[16] L.Y. Sandoval, 'Institución educativa y empresa: dos organizaciones humanas distintas', Eunsa, Pamplona, 2008.

[17] F. Altarejos, and C. Naval, 'Filosofía de la Educación', pp. 175-179, Eunsa, Pamplona, 2004.

[18] M. Norling, 'In Innovation, Is Patience a Virtue?' Research-Technology Management, Vol.52, No, 3, pp. 1823, 2009.

[19] T. McLaughlin, 'The educative importance of Ethos',p. 319, British Journal of Educational Studies, Vol. 53, No. 3, pp. 306-325, 2005.

[20] T. McLaughlin, 'The educative importance of Ethos',pp. 308-309, British Journal of Educational Studies, Vol. 53, No. 3, pp. 306-325, 2005.

[21] F. Altarejos, 'El Ethos docente: una propuesta deontológica', in Ética docente, pp. 101-102, Ariel, Barcelona, 2003.

[22] C. Cardona, La ética del quehacer educativo', p. 19, Rialp, Madrid, 2001.

[23] F. Altarejos, 'El Ethos docente: una propuesta deontológica', in Ética docente, p. 117, Ariel, Barcelona, 2003.

[24] J. Sumsion, 'Caring and Empowerment: a teacher educator's reflection on an ethical dilemma', Teaching in Higher Education, Vol, 5, No. 2, pp. 167-179, 2000.

[25] F. Altarejos, 'El Ethos docente: una propuesta deontológica', in Ética docente, pp. 117-118, Ariel, Barcelona, 2003.

[26] A. Caza, B.A. Barker, K.S. Cameron, 'Ethics and ethos: The buffering and amplifying effects of ethical Behavior and virtuousness', Journal of Business Ethics, Vol. 52, No. 2, pp.169-178, 2004. 